\title{
Elitist Democracy as the Root of Populist Counter- Revolution: A Theoretical Approach
}

\author{
Demokracja elitarystyczna jako przyczyna populistycznej kontrrewolucji - \\ ujęcie teoretyczne
}

\section{- Abstract •}

The article aims to critically discuss elitist democracy as one of the possible causes of the contemporary crisis of liberal democracy. The research problem is the question about the essential elements of the concept of elitist democracy, which potentially account for the populist counter-revolution aimed at changing the political systems formed after 1989.

The theoretical background of this paper is provided by the studies on the crisis of democracy, which have been conducted in recent years and presented by Jan Zielonka, or the duets of Ivan Krastev and Stephen Holmes as well as Roger Eatwell and Matthew Goodwin.

The analysis makes it possible to state that relations between elites and non-elites are crucial for elitist democracy, and they include the process of elites distancing themselves from non-elites, depreciating the needs of non-elites and their importance within the political system, and privileging the position of the elites. In turn, the indicated features of elitist democracy constitute the areas of populist criticism of liberal democracy.

\section{- Abstrakt •}

Celem artykułu jest krytyczne spojrzenie na problematykę demokracji elitarystycznej, rozpatrywanej jako jedna z potencjalnych przyczyn współczesnego kryzysu demokracji liberalnej. Problemem badawczym jest pytanie o istotne elementy koncepcji demokracji elitarystycznej, które stanowią potencjalne wyjaśnienie populistycznej kontrrewolucji zmierzającej do zmiany systemów politycznych ukształtowanych po 1989 roku.

Podjęte w artykule rozważania odnoszą się do studiów nad kryzysem demokracji, które zaprezentowane zostały w ostatnich latach m.in. przez Jana Zielonkę czy też duety Iwana Krastewa i Stephena Holmesa oraz Rogera Eatwella i Matthew Goodwina.

Przeprowadzona analiza pozwala określić, iż kluczowe dla demokracji elitarystycznej są relacje pomiędzy elitami a nie-elitami, na które składają się: proces dystansowania się elit wobec nie-elit, deprecjonowanie potrzeb nie-elit i ich znaczenia w ramach systemu politycznego oraz uprzywilejowanie pozycji elit. Wskazane cechy demokracji elitarystycznej stanowią z kolei obszary populistycznej krytyki demokracji liberalnej. 
Keywords: elitist democracy; crisis of liberal democracy; counter-revolution; populism
Słowa kluczowe: demokracja elitarystyczna; kryzys demokracji liberalnej; kontrrewolucja; populizm

\section{Introduction}

The scientific and journalistic discussions on the concept of the crisis or eclipse of liberal democracy conducted in recent years sometimes lead to terminological confusion. This situation is perfectly reflected in discussions on the issues of contemporary populism, which are often burdened with the lack of terminological precision; thus, it is impossible to construct a single scientific definition (Pacześniak $\&$ De Waele, 2010, p. 8). Moreover, what seems to make this issue even more problematic is a number of secondary or supplementary concepts emerging in this debate, which are also interpreted ambiguously. Categories that can be mentioned in this context include majoritarian democracy (Ciszewski, 2018), illiberal democracy (Antoszewski, 2018b; Zakaria, 2004), populist democracy, reverse democratization, Potemkin democracy, and elected autocracy (Dawson \& Hanley, 2016, pp. 20-34; Ágh, 2015, p. 4; Bureš \& Květina, 2018, p. 95). One of these concepts is also the category of elitist (oligarchic) democracy, which is the subject of the analysis presented in this text.

There is no doubt that discussions about elitist democracy sound completely different today than they did at the beginning of the $21^{\text {st }}$ century. Successes of populist groups, changes in party systems and their populization, reorientation towards post-populism (Hermet, 2010, pp. 44-48; Eatwell \& Goodwin, 2020, pp. 273-295) as well as attempts to implement the postulates of majoritarian or illiberal democracy (Antoszewski, 2018b) have made the category again the subject of intense discussions among political scientists.

The contemporary significance of elitist democracy stems mainly from the fact that this category, like the illiberal democracy described by Andrzej Antoszewski (2018b, p. 12), has been transferred from the language of the doctrine describing political reality to the language of politics, and it is used to criticize liberal democracy as its modern variant. Therefore in this article, elitist democracy is treated at the ontological level as a specific, modern version of liberal democracy, perceived by populists as its degeneration, which Jan Zielonka (2018) describes as undemocratic liberalism. This is also the starting point for this article, the aim of which is to critically look at the essence of elitist democracy, considered as one of the potential causes of the contemporary crisis of liberal democracy, and to define the theoretical background of this phenomenon. This task is in line with the contemporary 
need for precise concepts in political science, so necessary to maintain the quality and correctness of scientific discussion.

The research problem is the question as to which essential elements of the concept of elitist democracy potentially account for the populist counter-revolution. The main research question should be supplemented with an auxiliary question of how to define the concept of elitist democracy today.

The discussion is based on the hypothesis that in its contemporary characterization the elitist democracy is a theoretically coherent concept that explains the populist critique of liberal democracy, taking into account the unique position of the elites alienating themselves from non-elites and the sense of the elite's superiority over the people.

The theoretical background of this paper is provided by the studies on the crisis of democracy conducted in recent years and presented by such authors as Jan Zielonka (2018), or the duets of Ivan Krastev and Stephen Holmes (2020) as well as Roger Eatwell and Matthew Goodwin (2020).

What should be also explained in the introduction is the eponymous concept of populist counter-revolution, which is a reference to the perspective proposed by Jan Zielonka (2018) on the contemporary problems of liberal democracy. In this approach, counter-revolution would mean opposition to the changes brought about by the revolution of 1989 and, at the same time, the desire to dismantle the system created after the fall of the Berlin Wall, which has been articulated by groups referred to as populist (Zielonka, 2018, pp. 19-20). An important element of the counter-revolution would also be the replacement of the elites that over the last three decades have been responsible for shaping the criticized situation.

\section{Elitization of Democracy}

Describing the crisis of liberal democracy in Europe, Jan Zielonka (2018, p. 91) focuses on determining the causes of this situation that can be found in liberalism itself; he states that the type of democracy favored by liberals is elitist or even oligarchic. This sentence covertly introduces a relationship intuited by Zielonka - that democratic systems tend towards their elitist version, which simultaneously provokes the contemporary counter-revolutionists to criticize and object to this state of affairs.

Considered in a broader perspective, elitization of democracy is closely connected with the tension accompanying the relations between democracy and liberalism. Andrzej Antoszewski points, i.a., to the problem that liberal democracy combines 
both liberal values (such as popular sovereignty, equality, majority rule and equal voting rights) and democratic ones (individual autonomy, freedom, human rights, guarantees of minority rights) (Antoszewski, 2018a, p. 51; Sartori, 1998, p. 470; Bartyzel, 2002, p. 71). However, such synthesis could not have been achieved without any costs. Democracy had to abandon the metaphorical construct of "general will" as well as the concept of indirect democracy and anti-parliamentarism, while liberalism had to reject elitism (Bartyzel, 2002, p. 71).

In the context of this study it should be emphasized that liberalism is antiegalitarian in its essence. It is a method of creating and supporting not democracy but aristocracy, whereas democracy is built on a principle of equality and strives to eradicate differences and inequalities (Sartori, 1998, pp. 470-471).

From the perspective presented by Andrzej Antoszewski (2018a, p. 51), the democratic and the liberal component are intended to balance one another and stop each other from degenerating, thus preventing the reduction of the term "democracy" to competitive elections and the resulting dominance of the majority. On the other hand, both components allow a broader group of interested citizens, not limited to narrowly understood elites, to participate in political processes.

The eponymous elitist democracy is not a new category that has emerged during the contemporary crisis of liberal democracy. On the contrary, it has its place in the analyses of the political reality of the $20^{\text {th }}$ century (Bealey, 1996; Hayward, 2010; Lasch, 1997; Walker, 1966), which today is being defined anew.

However, as the problems of contemporary liberal democracy with its changes gravitating towards non-liberal or majoritarian democracy are in many cases rooted in its leaning towards elitization, the issue of elitist democracy appears to be one of more significant elements of the academic discussion on the successes of populists, particularly as it concerns the question of legitimacy of the democratic system itself. As noted by researchers, the issue of elitist (oligarchic) democracy is also the matter of social acceptance of political and economic diversification - acceptance which currently is at the brink of exhaustion (Eatwell \& Goodwin, 2020). This is also highlighted by Jan-Werner Müller (2020), who in his list of factors contributing to the crisis of liberal democracy (such as populism and the threat of authoritarianism) includes the cultural dimension of objection against liberal elites.

The problematics of elites and elitization of democracy is a central issue, e.g., in the "four Ds" model of national populism proposed by Eatwell and Goodwin (2020, pp. 20-23), who ascribe the sources of both populism and the crisis of liberal democracy to endogenous problems of democracy, describing the mentioned D-features of populism as processes that have been occurring over the last decades and shaped the contemporary form of this phenomenon. The first of the four ele- 
ments is the elitist character of liberal democracy, which results in distrust towards politicians and democratic-liberal institutions. The other features of populism include destruction of historical identities and lifestyles of a national group, caused by the conviction that supranational structures are preponderant over nations, as well as by migration, political correctness, etc.; deprivation resulting from incomebased social inequalities and loss of faith in a better future; and de-alignment - decay of bonds between voters and traditional political parties, with the latter losing trust and support of the former.

The problems with elitization of democracy have been noted by other researchers focused on the contemporary condition of democracy, such as Jan Zielonka (2018, p. 97), who stresses the alienation of elites from voters, which is visible even at the level of perception of needs. He claims that there is much truth in the statement that democracy is becoming progressively oligarchic; a relatively small elite attempts to rule according to their vision of the world, without listening to their own electorate. In addition, elites are convinced of their infallibility, as emphasized by Yuval Noah Harari (2018, p. 22); he notes that following Brexit, the liberal elites, who have thought themselves inerrant, were "shocked and disoriented", and unable to understand how the history veered off its scheduled course. The reason was their inability to adopt any interpretation perspective other than their own, which would have allowed them to understand the reality.

This inability to efficiently perceive the surrounding reality as well as lack of sensitivity towards social issues can be ascribed to elites functioning in the imaginary world of their own (mis)conceptions regarding, e.g., the needs and daily life of non-elites. Accepting such an explanation would highlight even more strongly the existence of the gap between elites and the rest of the society. This situation would also be a significant factor in the process of elites' alienation, and could be a confirmation that democracy is undergoing the process of elitization. This mechanism was well explained several decades ago by Christopher Lasch (1997, p. 27), an American critic of liberal democracy, who claimed that the problem of our society is not that the rich have too much money but that nowadays the money isolates them from ordinary life to a much greater degree than it used to.

Another dimension of elites' alienation reflects their attitude towards the majority - depreciating the latter's value and ability to be independent, e.g., in expressing their expectations and political views. Jan-Werner Müller (2020) indicates that there is a mechanism operating among the elites through which they ascribe the problem with populism to the existence of "impressionable citizens", who are easily seduced by irrational proposals and thus responsible for the disastrous effects of the new anti-liberalism. Paradoxically, such approach highlights even more clearly the 
problem of the divergence between the elites and the people. Depreciation of nonelites' capability to judge the reality accurately leads to negating the need for their participation in politics.

Thus, we can read anew the critique of democratic elites proposed in the 1990s by Lasch $(1995 ;$ 1997). As observed by Leszek Nowak (2018, pp. 46-47), in Lasch's eyes one of the aspects of the liberal democracy crisis was a rebellion - yet not the one envisioned by Ortega y Gasset (2006). Lasch reverses Ortega's thesis, stating that it is not the masses that have rebelled, but the elites; today all the negative features ascribed by Ortega to the masses are characteristic of elites (Nowak, 2018, pp. 46-47; Lasch, 1997, pp. 34-35).

Referring to the issues analyzed by Lasch, Nowak (2018, pp. 46-47) emphasizes that the lifestyle of elites seems to be a parody of liberal values. Elites are fascinated by capitalism, and their individualism turns into narcissistic egoism; they despise traditional values and provinciality, while their way of life embodies cosmopolitan values. They are perfectly mobile, which means that they feel no loyalty towards any community or place. As a consequence, liberal democracy becomes a collection of procedures and institutions allowing the liberal elite to lead their lives without the sense of responsibility for the rest of the society.

The presented viewpoint defining the theoretical framework of the concept of "elitist" democracy corresponds to the idea of democracy in its exclusive-democratic version, associated with the concept of deliberative democracy (Grygieńc, 2017, p. 16; Perlikowski, 2020, pp. 150-163). Distinguishing its radical version, Janusz Grygieńć (2017, pp. 56-57) describes it as a tendency towards restricting the participation in the democratic debate only to the group of experts, who are furthermore elected through undemocratic decisions. Grygieńc evokes such representatives of this approach to democracy as Daniel Bell (1999, pp. 70-87) and Cass Sunstein (2009, pp. 207-227), who argue that actions of this kind are a response to the irrationality of public debate. They also emphasize the importance of and need for political responsibility and professionalism, considering that decisions are more likely to be responsible (and not based on selfish interest and emotions) if they are made by elites.

The other approach described by Grygieńć (2017, p. 16) is a less radical, yet still exclusive version of democracy. It can be understood as a system in which the power should be handed over to the elites and experts so that they can pursue citizens' best interest in their name. In this context, Grygieńc (2017, p. 40) recalls the viewpoint of William Riker (1982, p. 244), invoking the proposition of a minimalist version of liberal democracy, which would mean limiting citizens' direct influence on shaping the public sphere only to electing the political elites. 
The thoughts of Jan Zielonka (2018, p. 24) also fit into the exclusive-democratic narration on the reasons for the success of non-liberal democracy. Zielonka notes that nowadays more and more power is entrusted to institutions not chosen through general elections, for example, central banks or constitutional courts. It is often argued that such actions, undertaken in the spirit of exclusive democracy, are to ensure that the society's pressure (considered irresponsible) will not lead to making political decisions governed by passions instead of reason. This kind of argumentation brings us close to the debate on "technocratization" of the people holding power. Artur Laska (2017, p. 55) emphasizes that the conflict between the people and the elites, crucial for populists, can be justified as a part of the narration about the rebellion of those who, sick of the experts' rule, take matters into their own hands, removing the technocrats and entrusting power to "ordinary people".

The above characterization can be complemented by the perspective of the masses (non-elites), imbued with subjectivism. Eatwell and Goodwin (2020, p. 59) emphasize that the wave of distrust afflicting contemporary democratic systems is caused by the mentioned strong conviction of the voters that they do not participate in the democratic debate, combined with the desire to have a more substantial influence on decisions that concern themselves. The researchers point out that the problem with liberal democracy does not result from the ideological objection of populists against the institution of democracy itself; it is founded instead on the fears regarding the functioning of democracy in which people have no influence on political decisions (Eatwell \& Goodwin, 2020, p. 107). A primary direct effect of the described process is lack of trust towards the elites and the entire political system, determined by lack of political agency and the feeling that a single vote is insignificant, experienced by increasingly larger groups in the society (Eatwell \& Goodwin, 2020, p. 59).

This leads to the conclusion that a space for populism has been created by the very development of liberal democracy and the desire to marginalize the masses and thus implement the "elitist" conception of democracy. It has opened a space for populists, who have begun to represent people neglected or even despised by political and economic elites, progressively indifferent and technocratic (Eatwell \& Goodwin, 2020, p. 106). According to Zielonka (2018, p. 59), if approached in this way, liberalism no longer protects the minority against the majority but becomes the rule of a minority - of career politicians, journalists, bankers and experts, who tell the majority what is best for them. This opinion is seconded by Colin Crouch (2004, pp. 19-20), who over a decade ago wrote about post-democracy where the power was taken over by small elite circles operating behind a democratic facade. To this, Marek Migalski adds a comment on the post-democratic or non- 
democratic system that does not express the will of the people, sublimating it into universal consumption (Migalski, 2015, pp. 8, 185-186).

The process whose theoretical frame has been presented in the article is one of the elements of the contemporary crisis of democracy. However, a reservation should be made here that the successes of populists (or, as Zielonka prefers to call them, counter-revolutionists) should be considered in a broader perspective, counted not in years but decades. Eatwell and Goodwin (2020, pp. 107-108) are of the opinion that blaming populists for the challenges faced by liberal democracy is putting the matters in the wrong order as many people had been disappointed by democratic policy long before the populists' successes. Adopting this perspective also allows addressing the issue of the influence of elitist democracy on the condition of today's politics. Over the last decades the elitization of democracy has been criticized for different reasons; the ones listed by Jack Hayward (2010, p. 309) included the conditions of post-communist transformation in Central and Eastern Europe, the deficit of democracy in the EU countries as well as economic problems and corruption at the intersection of politics and business. However, it is the recent events that have made this criticism truly poignant.

In the recent years, the disappointment with the functioning of democracy has been intensified by a variety of factors, including a financial crisis, a migration crisis, social stratification, and deprivation (Zybertowicz et al., 2015, pp. 399-400 ), as well as media bubbles and the polarization of opinions they determine (Szułdrzyński, 2020). These problems ultimately lead to growing differences between elites and non-elites, where the latter criticize the former as the expected standard of living is impossible to achieve. Another symptom of this phenomenon is the situation where well-educated elites, whose background and perspectives differ significantly from those of an average citizen, gain further advantage by participating in the new ruling elite, connected by networks of both informal and formal contacts entwined around democratically elected national government (Sandel, 2020; Eatwell \& Goodwin, 2020, pp. 106-107). To quote Lasch again (1997, pp. 27-28), at the core of this division lies not only economic inequality but also the question of social (civic) equality. The research of Ben Stanley (2019, pp. 23-24) demonstrated, e.g., that the factors influencing the voters' decisions in Poland in 2015 were the issues of cultural identity and the narrations negative towards political elites, further exacerbated by populist attitudes. Actual economic reality turned out to be less significant. 


\section{Conclusions}

Answering the research questions posed in the introduction as to how elitist democracy should be defined, it has to be noted first that it is not a political system alternative to liberal democracy. The analyzed conceptions present it rather as an effect of the evolution of democracy towards oligarchy and technocracy, which can be perceived as limitations of the sphere of democracy. Thus, the category of elitist democracy is a potential tool for populists/counter-revolutionists to use in pursuit of their policies.

Considering the essence of elitist democracy, it should be emphasized that its crucial element are relations between elites and non-elites, which comprise the process of elites distancing themselves from non-elites (understood as lack of political empathy of elites towards non-elites, alienation of the former and separation from the latter) as well as the importance of elites within the political system and their privileged position. Both the cause and effect of adopting such a perspective is the conviction of the voters that elites are unable to act in service of public interest (Hayward, 2010, p. 309).

The analysis also provides an answer to the main research question. The features of elitist democracy listed above are in contradiction with the goals of populists, who want to restore (at least declaratively) such things as subjectivity of the people (Albertazzi \& McDonnell, 2008, pp. 218-219; Rydliński, 2019). Thus, the elitist version of democracy is the area of populist criticism of liberal democracy and at the same time the basis for counter-revolutionary actions.

Regarding the proposed research hypothesis, the concept of elitist democracy can be interpreted as a coherent one that explains the populist criticism of liberal democracy, taking account of the features listed above. A reservation should be made, however, that this concept by no means lays claim to being comprehensive or the only one that can offer an answer as to the reasons for counter-revolution and the problems of contemporary liberal democracies. 


\section{References:}

Ágh, A. (2015). De-Europeanization and De-democratization Trends in ECE: From the Potemkin Democracy to the Elected Autocracy in Hungary. Journal of Comparative Politics, 8(2), 4-26.

Albertazzi, D., \& McDonnell, D. (2008). Conclusion: Populism and Twenty-First Century Western European Democracy. In: D. Albertazzi, \& D. McDonnell (Eds.). Twenty-First Century Populism. The Spectre of Western European Democracy (pp. 217-223). London: Palgrave Macmillan.

Antoszewki, A. (2018a). Demokracja nieliberalna jako projekt polityczny. In: K.A. Wojtaszczyk, P. Stawarz, \& J. Wiśniewska-Grzelak (Eds.). Zmierzch demokracji liberalnej? (pp. 51-67). Warszawa: Oficyna Wydawnicza ASPRA-JR.

Antoszewski, A. (2018b). Demokracja nieliberalna jako projekt polityczny. Przeglad Europejski, 2, 11-31. DOI: 10.5604/01.3001.0013.0788.

Bartyzel, J. (2002). Demokracja. Radom: Polskie Wydawnictwo Encyklopedyczne.

Bealey, F. (1996). Democratic Elitism and the Autonomy of Elites. International Political Science Review, 17(3), 319-331. DOI: 10.1177/019251296017003009.

Bell, D.A. (1999). Democratic Deliberation: The Problem of Implementation. In: S. Macedo (Ed.). Deliberative Politics: Essays on Democracy and Disagreement (pp. 70-87). Oxford: Oxford University Press.

Bureš, J., \& Květina, J. (2018). Post-Communist Regimes in Central Europe Thirty Years After: Time for Another Revolution? In: T. Čižik, \& I. Borárosová (Eds.). The Future Revolutions in Central and Eastern Europe (pp. 85-104). Bratislava: Centre for European and North Atlantic Affairs.

Ciszewski, W. (2018). Czy demokracja to rządy większości wyłonionej w wyborach? Avant. The Journal of the Philosophical-Interdisciplinary Vanguard, 9(1), 163-177. DOI: $10.26913 / 90102018.0103 .0010$.

Crouch, C. (2004). Post-Democracy. Oxford: Wiley Blackwell.

Dawson, J., \& Hanley, S. (2016). What's Wrong with East-Central Europe? The Fading Mirage of the "Liberal Consensus". Journal of Democracy, 27(1), 20-34. DOI: 10.1353/jod.2016.0015.

Eatwell, R., \& Goodwin, M. (2020). Narodowy populizm. Zamach na liberalna demokrację. Katowice: Wydawnictwo Sonia Draga.

Grygieńć, J. (2017). Demokracja na rozdrożu. Deliberacja czy partycypacja polityczna? Kraków: Wydawnictwo Universitas.

Harari, Y.N. (2018). 21 lekcji na XXI wiek. Warszawa: Wydawnictwo Literackie.

Hayward, J. (2010). Populistyczne wyzwanie dla demokracji elit w Europie. In: O. Wysocka (Eds.). Populizm (pp. 309-337). Warszawa: Wydawnictwo Uniwersytetu Warszawskiego.

Hermet, G. (2010). Przemiana populizmu. In: J.M. De Waele, \& A. Pacześniak (Eds.). Populizm w Europie. Defekt i przejaw demokracji? (pp. 35-48). Warszawa: Oficyna Naukowa.

Krastev, I., \& Holmes, S. (2020). The Light That Failed: Why the West Is Losing the Fight for Democracy. New York: Pegasus Books. 
Lasch, Ch. (1995). The Revolt of the Elites and the Betrayal of Democracy. London, New York: Norton.

Lasch, Ch. (1997). Bunt elit. Kraków: Wydawnictwo Platan.

Laska, A. (2017). Populizm jako implikacja technokratyzacji polityki. In: F. Pierzchalski, \& B. Rydliński (Eds.). Autorytarny populizm w XXI wieku. Krytyczna rekonstrukcja (pp. 49-68). Warszawa: Dom Wydawniczy Elipsa.

Migalski, M. (2015). Koniec demokracji. The End of Democracy. Warszawa: The Facto.

Müller, J.W. (2020). Strach i wolność. O inny liberalizm. Warszawa: Fundacja Kultura Liberalna.

Nowak, L. (2018). Kruche podstawy liberalnej demokracji. In: K.A. Wojtaszczyk, P. Stawarz, \& J. Wiśniewska-Grzelak (Eds.). Zmierzch demokracji liberalnej? (pp. 31-50). Warszawa: Oficyna Wydawnicza ASPRA-JR.

Ortega y Gasset, J. (2006). Bunt mas. Warszawa: Wydawnictwo Muza.

Pacześniak, A., \& De Waele, J.M. (Eds.) (2010). Populizm w Europie. Defekt i przejaw demokracji? Warszawa: Oficyna Naukowa.

Perlikowski, Ł. (2020). Pluralizm i racjonalność w świetle idei demokracji deliberatywnej. Płock: Wydawnictwo Naukowe Mazowieckiej Uczelni Publicznej w Płocku.

Riker, W.H. (1982). Liberalism against Populism: A Confrontation between the Theory of Democracy and the Theory of Social Choice. San Francisco: W.H. Freeman.

Rydliński, B. (2019). Demokracja nieprzedstawicielska - egalitarne „wyjście awaryjne” czy narzędzie autorytarnych populistów? Annales Universitatis Paedagogicae Cracoviensis. Studia Politologica, 23, 93-102. DOI: 10.24917/20813333.23.7.

Sandel, M.J. (2020). Tyrania merytokracji. Co się stato z dobrem wspólnym? Warszawa: Wydawnictwo Naukowe PWN.

Sartori, G. (1998). Teoria demokracji. Warszawa: Wydawnictwo Naukowe PWN.

Stanley, B. (2019). A New Populist Divide? Correspondences of Supply and Demand in the 2015 Polish Parliamentary Elections. East European Politics and Societies and Cultures, 33(1), 17-43. DOI: 10.1177/0888325418783056.

Sunstein, C.R. (2009). Infotopia. O zbiorowym procesie wytwarzania wiedzy. Warszawa: Wydawnictwo Sejmowe.

Szułdrzyński, M. (2020). Media społecznościowe kontra liberalna demokracja, jaką znamy. In: M. Bernaczyk, T. Gąsior, J. Misiuna, \& M. Serowaniec (Eds.), Znaczenie nowych technologii dla jakości systemu politycznego. Ujęcie politologiczne, prawne $i$ socjologiczne (pp. 27-40). Toruń: Wydawnictwo Naukowe Uniwersytetu Mikołaja Kopernika.

Walker, J.L. (1966). A Critique of the Elitist Theory of Democracy. The American Political Science Review, 60(2), 285-295. DOI: 10.2307/1953356.

Zakaria, F. (2004). The Future of Freedom: Illiberal Democracy at Home and Abroad. New York: W.W. Norton \& Company Inc.

Zielonka, J. (2018). Kontrrewolucja. Liberalna Europa w odwrocie. Warszawa: Wydawnictwo PWN.

Zybertowicz, A., Gurtowski, M., Tamborska, K., Trawiński, M., \& Waszewski, J. (2015). Samobójstwo oświecenia? Jak neuronauka i nowe technologie pustoszq ludzki świat. Kraków: Wydawnictwo Kasper. 